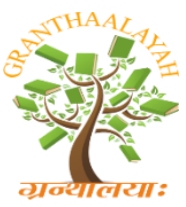

INTERNATIONAL JOURNAL OF RESEARCH GRANTHAALAYAH A knowledge Repository

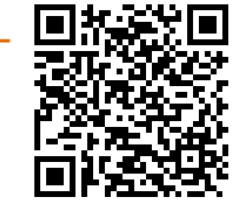

Social

\title{
AN ANALYSIS OF THE COMPLEX SENTENCES USED IN SELECTED THAI POLITICAL NEWS IN ONLINE BANGKOK POST
}

\author{
Janjira Kongsakorn $^{* 1}$, Prommintra Kongkaew ${ }^{2}$ \\ ${ }^{* 1,2}$ English Department, Graduate School, Ubon Ratchathani Rajabhat University, Thailand
}

DOI: https://doi.org/10.29121/granthaalayah.v5.i3.2017.1751

\begin{abstract}
The present work aimed to analyze complex sentences and study the types of the complex sentences as used in the selected Thai political news stories from online Bangkok Post. Four Thai political news stories were selected for the study. They were the news stories published in April 2016. The news stories were analyzed based on the following types: Adverbial clauses, relative clauses and nominal clauses. The study found that the complex sentence type which was used with the highest frequency was a nominal clause. It accounted for $44 \%$. The type of the complex sentence; which was ranked second in use was an adverbial clause. It accounted for $29 \%$. The type of the complex sentences which was least used was a relative clause. It represents $27 \%$.
\end{abstract}

Keywords: Complex Sentence; Thai Political News; Online Bangkok Post.

Cite This Article: Janjira Kongsakorn, and Prommintra Kongkaew. (2017). "AN ANALYSIS OF THE COMPLEX SENTENCES USED IN SELECTED THAI POLITICAL NEWS IN ONLINE BANGKOK POST." International Journal of Research - Granthaalayah, 5(3), 16-28. https://doi.org/10.29121/granthaalayah.v5.i3.2017.1751.

\section{Introduction}

English has been regarded as an international language and widely use around the world. English is the main language of books, newspapers, airports, international business and academic conferences, science, technology, diplomacy, sports, international competitions, pop music and advertising. English is the dominant business language and it has become almost a necessity for people to speak English if they are to enter a global workforce, research from all over the world shows that cross-border business communication is most often conducted in English. Because English importance in the global market place, learning if can change your life. In business life, the most important common language is obviously English. In addition to this, high-quality jobs need good understanding and ability to speak English. Therefore, companies can easily open out to other countries, and these companies generally employ graduates whose English is fluent and orderly. For example, the students who graduate from a university which takes English as a major language will find a better or high-quality job than other students who do not know 
English adequately. In other words, the student who knows English is able to be more efficient in his job because he can use the information from foreign sources and websites. They can prepare their assignments and tasks with the help of information. University graduates who are in an international company and business are needed to communicate with foreign workers. For instance, if their managers want them to share the company's data, they are expected to know English. Moreover, they will even have to go business trip for their company.

In these days, the most important thing for both university students and graduates is to follow the development in technology. For this reason, they have to learn common language. Certainly, they should not lose their interest on communicating with the world. However, some of the university students can't obtain English education in their university. Unfortunately, these people may lose their communication with worldwide subjects and topics. In short, they will not communicate foreign people. To prevent these people from lacking of speaking English, universities' administration will provide English education to them.

Professional people need newspapers. Engineers, doctors, scientists, professors and any other people in different professions need them to know the day-to-day developments regarding their particular fields. Politicians need them to keep up with status quo. Others read newspapers to know how the changes around them affect their life. Students read newspapers to broaden their knowledge by keeping up with recent developments in various fields, whether it be in politics, economics, science, sports or art and culture. Newspaper is an important tool of the learning process for students. In addition, students like to read English newspaper because it is a very useful device for them to improve their English skills. Reading newspapers every day is a must for students as it is highly useful and important source of self-study.

Newspapers are a tool to check the activities of the government, the parliamentary sessions, the Prime Minister's activities and etc. In addition, newspapers are sometime representative of the public to present the public's idea and comment on the government, the political parties, the government's politics and other political affairs. People check on the government by following the political news and they express their opinions through newspaper (Phanphanich, 1999 ).

One of the news which attracts a wide attention from the readers is the political news. It can be easily observed that a majority of the newspapers, except the sports newspaper, present the news of the political affairs and activities related to political news. More than of the newspapers is clearly devoted to this news. As politics is very close to the people one way or another, it is not possible to avoid this news.

People read the newspaper for different purposes. Some may read for an entertainment and some sports activities. Other may do it because they are interested in the world affairs which are going on across the globe. In the globalized age, in addition to being available in the printed media, the newspaper are also available online. Readers nowadays find it convenient to get access to the news online providing that they have access to the Internet. Two English newspapers which are available in Thailand are The Bangkok Post and The Nation. The former is the mass circulation paper. These two papers can be also read online. 
The Bangkok Post offers many kinds of news to readers such as political news, crime reports, sports news, entertainment, advertisements and international. This research focuses on political news because of its impact on readers. Political News is news which presents the reported activities and the movement of and administration and politician such as prime minister, the cabinet or the constitution division, the representative, the senate through an operation of the political parties which the news reporter should communicate for determining the facts- which will be separated point by point (Kansuwan, 1996).

Additionally, the style of language used in newspaper differs from that in textbooks. This is confirmed by Meksujit (2002) who found out in her research on grammatical structures used in business news in The Nation and The Bangkok Post that complex sentences occur at the highest rank among four types of sentences: simple, compound, complex, and compound - complex sentences.

Based on the studies examined, it is found that no study has been done on the complex sentences. This type of the sentences is found to have been used with a high frequency in the presenting different types of news. Therefore, it is deemed useful to conduct a study exclusively on the complex sentences used in the selected political news.

\section{Objectives of the Study}

- This study aims to analyze complex sentences used in the selected Thai political news in the online Bangkok Post.

- This study aims to examine the types of complex sentences used in the selected Thai political news in the online Bangkok Post.

\section{Research Questions}

- What are the patterns of complex sentences used in the selected Thai political news in the online Bangkok Post?

- Which types of sentence are frequently used in the selected Thai political news in the online Bangkok Post?

\section{Significance of the Study}

The study can enhance reader's more understanding of the sentences as the complex sentences consist of one or more clauses. The readers who have understood the structure of the complex sentences will find it simple to deal with reading passages written in the compound or complex sentences. In addition, they are expected to have less difficulty in identifying the main idea of the text. As for news reading, understanding of the complex sentence structure can be useful to readers who are keen to follow the news and learn more about the English usage.

\section{Scope of the Study}

The study focuses on the analysis of complex sentences used in selected Thai political news in the Bangkok Post. The analysis is based on four Thai political news selected from the Bangkok Post in April 2016. The political news are limited to only Thai political news in Thailand involving Thai government, Thai politicians, Thai political parties, government affairs, and parliamentary activities. 


\section{Materials and Methods}

The materials used in the study are four Thai political news stories. All news stories are purposively selected in April 2016 from the online Bangkok post www.bangkokpost.com/news. The Thai political news stories used in the study are the following:

1. NLA likely back second vote query

2. Senate-pick PM query gets nod

3. NCPO rebuts Pheu Thai's abuse of power comment

4. Democrats deal double blow to CDC draft
7 April 2016

8 April 2016

10 April 2016

11 April 2016

\section{Data Collection}

For the analytic purpose, all the selected news stories are carefully read. The complex sentences of all types used in the news stories are identified and collected.

\section{Data Analysis}

All the complex sentences which are collected from the selected news stories are categorized according to the subordinate clauses which modify the main clauses: adverbial clauses, relative/adjective clauses and nominal clause. In the first clause, the adverbial clauses of time, place, concession, and others are explored. The second category, the restrictive clauses and nonrestrictive clauses are examined. In the last category, all nominal clauses with different functions, for example the subject, the object and the complement are investigated.

An analysis of the complex sentences used in the Thai political news stories is conducted based on the structure consisting of a main clause and one or more subordination clauses: I phoned the police (main clause ) when I heard the shooting (subordinate clause ). It is to be noticed that subordinate clauses may be finite as shown in the above sample sentence. Subordinate clauses may be non - finite: I phoned the police (main clause) after hearing the shots (subordinate clause), (Jarvie, 1993). The present study analyses only the complex sentences which have finite subordinate clauses only. It will not deal with non-finite subordinate clauses. For example, the sentence 'While waiting for my friend, I feel hungry'. A non-finite subordinate clause as shown will not be dealt with in the present study.

In addition, in analyzing nominal clauses, the present study includes all types of noun clauses irrespective of functions.

Example : Noun clause as a subject:

What I learn is English.

Noun clause as a complement:

The question is when you should.

Noun clause as an objective:

They believe that the earth is flat.

Often the connective word 'that' used in the noun clauses is omitted:

He said ${ }_{x}$ he did not come. 
In the final step, the complex sentence types are calculated according to their frequency of use in the selected materials. The procedure of analyzing the complex sentences can be shown as below. The steps of analysis can be shown follows.

Collection of all collected complex sentences

Categorization: Adverbial Clauses

Categorization: Relative Clauses

Categorization: Nominal Clause

Frequency of the complex sentence types

\section{Results and Discussions}

A. Complex sentences modified by adverbials clauses: An Analysis of adverbials clauses used in Thai political news

News 1: "NLA likely to back second vote query" April 7, 2016 (Total 10.34\%)

1) Mr. Kittisak said the question should have one focus otherwise it will contravene the interim charter which allows only a single question to be asked at the planned referendum.

2) "If we also include 'Should the Senate vote in a no-confidence debate?' in the questions, it could be considered as two questions," he said.

3) Deputy Prime Minister Wissanu Krea-ngam said Wednesday the government would decide without delay what steps would be taken, "if the charter fails to pass at the referendum.

News 2: "Senate-pick PM query gets nod" April 8, 2016 (Total 44.82\%)

1) This means that if the draft charter and the extra question pass the August referendum,

2) They will also be forced to pay for any costs involved in holding a new referendum if the referendum is sabotaged and fails.

3) While the referendum bill gives the Election Commission (EC) the sole authority in organizing campaigns to encourage the public to vote in the referendum, the bill also prohibits any individuals from holding campaigns to persuade people to accept or reject the draft in the referendum.

4) Gen Somjate Boonthanom, chairman of an NLA committee vetting the referendum bill, told the meeting that unauthorized campaigns by individuals could spark a new round of conflict, If allowed by the bill,

5) Thanawat Sangthong, a member of the bill vetting panel, said that even the EC is not allowed explain the bill to the public as this could hurt its neutrality.

6) Only the CDC can spell out the full details of the draft, while the EC will be only responsible for publishing and distributing a summary of the draft charter to the public, and holding forums to discuss the draft's pros and cons,

7) While fellow member Wanlop Tankhananurak said people should have the right to express their opinions as long as they do so with good intentions. 
8) The change also eases pressure on the media which has the duty to disseminate both the pros and cons of the draft charter and could be at risk of violating the bill unless it is amended.

9) However, campaigns are banned because they may breach other people's rights and therefore freedom of expression should also be considered, Mr Sawaeng said.

10) The bill also allows at least 50 voters to petition the EC against vote counting at a polling station if irregularities are suspected.

11) The top three questions that got the most "Likes" were: "If the draft charter fails to pass the referendum

12) Do you agree that the previous 1997 constitution should be adopted as the country's new constitution?;

13) Do you agree that if the draft fails to pass the referendum, the government and the National Council for Peace and Order must resign en masse?

News 3: "NCPO rebuts Pheu Thai's abuse of power comment" April 10, 2016 (Total 6.89\%)

1) The NCPO's reaction came after the Pheu Thai released a statement last week urging the government to stop fuelling suspicions among the public and violating people's rights.

2) He felt embarrassed for the government after ambassadors of some countries in the European Union expressed concerns over order No 13/2016.

News 4: "Democrats deal double blow to CDC draft" April 14, 2016 (Total 37.93\%)

1) The public will lose if this is the case, said the former prime minister.

2) He said that would have a bigger effect as it will give them a majority in parliament.

3) He said while the charter draft is designed to rein in corruption, it drops the need for impeachment and opts for a court trial which would make it difficult to tackle corruption.

4) Especially the clauses on the appointed Senate, as the move requires support from at least one-third of senators who are all appointed by the NCPO, he noted.

5) Mr Abhisit also called on the NCPO to outline the next steps in case the charter draft is rejected in the referendum, saying it should do so as soon as possible.

6) Mr Abhisit also called on the NCPO to outline the next steps in case the charter draft is rejected in the referendum, saying it should do so as soon as possible.

7) "It's still hard to say if we will vote for it or against it. Some people reject it before it is complete. Some people support it no matter what ,because they don't like the people who reject it."

8) "It's still hard to say if we will vote for it or against it. Some people reject it before it is complete. Some people support it no matter what ,because they don't like the people who reject it."

9) "It's still hard to say if we will vote for it or against it. Some people reject it before it is complete. Some people support it no matter what,because they don't like the people who reject it."

10) "They pay no attention to, nor make any effort to understand, the NCPO's work even though we are doing good things to bring about changes. That's fine.

11) But they are critical of our efforts in implementing reforms. That's because they are afraid once we succeed, people won't elect them to office," he said. 
B. Complex sentences modified by Relative clauses: An Analysis of Relative clauses used in four selected Thai political news

News 1: "NLA likely to back second vote query" April 7, 2016 (Total 28.57\%)

1) The National Legislative Assembly (NLA) is expected to vote in support of a question to be added in a national referendum that could support the powers of an appointed Senate to select a prime minister.

2) NLA members (about 60\%) are in favour of adding the question of whether parliament, in which the selected Senate is seen to be under control of the regime,

3) Mr Kittisak said the question should have one focus otherwise it will contravene the interim charter which allows only a single question to be asked at the planned referendum.

4) An NLA source said NLA whips have agreed the extra question which could be asked at a charter referendum scheduled to take place in early August,

5) Should be the one suggested by the National Reform Steering Assembly (NRSA), which is whether an appointed Senate should be allowed to select the prime minister during the post-election transitional period.

News 2: "Senate-pick PM query gets nod" April 8, 2016 (Total 39.28\%)

1) The content is seen as a challenge to the Constitution Drafting Committee's (CDC) charter draft which gives this mandate to the House of Representatives.

2) NLA members who are expected to propose different questions include Gen Somjet Boonthanom, Gen Singsuek Singphrai, Adm Chumnoom Artwong, and Wanlop Tangkhananurak

3) Pictures or voice messages via any media that are false, aggressive, rude, inflammatory or coercive in order to persuade eligible voters not to vote, to vote in a particular way or to choose the no-vote option in the referendum.

4) The National Legislative Assembly (NLA) on Thursday voted in favour of a question to be added in the referendum on the draft constitution that will enable an appointed Senate to help select a prime minister. "

5) The regime-appointed assembly also passed a bill to facilitate the referendum on the draft charter in which a penalty of 10 years' imprisonment could be imposed against those who provoke violence disruptions of the referendum.

6) The regime-appointed assembly also passed a bill to facilitate the referendum on the draft charter in which a penalty of 10 years' imprisonment could be imposed against those who provoke violence or disruptions of the referendum.

7) The Constitution Drafting Committee (CDC) will have to revise the new constitution which only gives the mandate to select a prime minister to the House of Representatives.

8) The bill imposes a jail sentence of up to 10 years and a fine of up to 200,000 baht for those who disrupt the referendum,

9) Any private companies or individuals who arrange for vehicles to transport voters to polling stations for free during the referendum will also face a jail term of up to 10 years and a fine of up to 200,000 baht.

10) Said Mr.Thanawat who is on the Council of State, the government's legal advisory body. 
11) Following talks with the critics, the bill vetting panel agreed to change the language of the bill which "allows the public freedom to express and disseminate their opinions on the draft charter's content,

12) The change also eases pressure on the media which has the duty to disseminate both the pros and cons of the draft charter and could be at risk of violating the bill_unless it is amended.

13) "Referendum" asked people to come up with questions that should be added in the referendum on the draft charter.

14) The top three questions that got the most "Likes" were: "If the draft charter fails to pass the referendum

News 3: "NCPO rebuts Pheu Thai's abuse of power comment" April 10, 2016 (Total 10.71\%)

1) NCPO spokesman Winthai Suvaree on Saturday maintained that soldiers were strictly enforcing the law, which he said cannot be considered a violation of human rights.

2) Col Winthai said authorities enforce the law case by case, which does not infringe on anyone's rights and protects law-abiding citizens.

3) Mr Watana, who has recently attended several "attitude adjustment" sessions with the military over critical remarks towards the government, said the regime violated human rights.

New 4: "Democrats deal double blow to CDC draft" April 14, 2016 (Total 18.51\%)

1) They warned a "yes" vote to the second question, which would pave the way for an appointed Senate to intervene in the selection of a prime minister, could escalate political conflicts.

2) If the extra question gets a majority "yes" vote, it will force the Meechai panel to revise the constitution draft which currently does not allow the upper House to choose the prime minister.

3) He said while the charter draft is designed to rein in corruption, it drops the need for impeachment and opts for a court trial which would make it difficult to tackle corruption.

4) Moreover, it would be difficult to amend the new charter, especially the clauses on the appointed Senate, as the move requires support from at least one-third of senators who are all appointed by the NCPO, he noted.

5) Because they don't like the people who reject it."

C. Complex sentences modified by Nominal clauses: An Analysis of nominal clauses used in four selected Thai political news

News 1: "NLA likely to back second vote query" April 7, 2016 (Total 31.82\%)

1) He said the findings were based on an internal survey through the Line chat application.

2) Mr. Kittisak said the question should have one focus otherwise it will contravene the interim charter 
3) An NLA source said NLA whips have agreed the extra question which could be asked at a charter referendum scheduled to take place in early August,

4) The source said other possible questions include whether parliament should have a mandate to appoint or impeach cabinet members

5) The source said other possible questions include whether parliament should have a mandate to appoint or impeach cabinet members and whether parliament should have the powers to supervise an elected government.

6) Mr. Wanlop said he will Thursday propose including a question of whether both the lower and upper houses should vote in a no-confidence motion

7) Mr. Wanlop said he will Thursday propose including a question of whether both the lower and upper houses should vote in a no-confidence motion against cabinet ministers accused of graft and corruption.

8) He said senators should be able to join the House of Representatives in voting on a censure motion, but they should not be empowered to initiate a no-confidence vote.

9) NLA vice-president Surachai Liangboonlertchai admitted Wednesday that NLA members are divided over the wording

10) NLA whip Adm Yutthana Fakpholngam said it is up to the NLA to vote on what the questions should be and insisted there is no "prescription from the military regime".

11) NLA whip Adm Yutthana Fakpholngam said it is up to the NLA to vote on what the questions should be and insisted there is no "prescription from the military regime".

12) The bill recommends the courts suspend the electoral rights of violators for up to five years.

13) Deputy Prime Minister Wissanu Krea-ngam said Wednesday the government would decide without delay

14) Deputy Prime Minister Wissanu Krea-ngam said Wednesday the government would decide without delay what steps would be taken

News 2: "Senate-pick PM query gets nod" April 8, 2016 Total 15.91\%)

1) The NRSA suggested that voters be asked whether an appointed Senate should be allowed to join the House .....

2) The NRSA suggested that voters be asked whether an appointed Senate should be allowed to join the House of Representatives in voting to select a prime minister during the post-election transition period.

3) Gen Somjate Boonthanom, chairman of an NLA committee vetting the referendum bill, told the meeting that un authorised campaigns by individuals could spark a new round of conflict.

4) NLA member Tuang Atthachai said that the ban on such campaigns could be construed as a violation of freedom of expression,

5) Tankhananurak said people should have the right to express their opinions as long as they do so with good intentions.

6) Sawaeng Boonmee, a member of the vetting panel, said the principle of holding a referendum is to provide the public with enough information to make their

7) Do you agree that a charter provision giving amnesty for the government and the coupmakers for staging the coup should be revoked?" 
News 3: "NCPO rebuts Pheu Thai's abuse of power comment" April 10, 2016 (Total 20.45\%)

1) The National Council for Peace and Order has rejected the Pheu Thai Party's accusation that the military has used its power to violate human rights.

2) NCPO spokesman Winthai Suvaree on Saturday maintained that soldiers were strictly enforcing the law, which he said cannot be considered a violation of human rights.

3) The statement said the rights of many people had been violated by the military during its administration since the May 22, 2014 coup.

4) Col Winthai said most people have been satisfied with the government's law enforcement.

5) He said the government always enforced the law in a careful manner to benefit the country and prevent the government from being unfairly discredited.

6) Col Winthai said authorities enforce the law case by case

7) The NCPO spokesman also denied allegations it was using excessive power to detain political dissidents.

8) He said offering divergent political opinions is accepted but they must be expressed through proper channels.

9) Meanwhile, Pheu Thai Party member Watana Muangsook on Saturday posted on his Facebook page that he felt embarrassed for the government

News 4: “Democrats deal double blow to CDC draft" April 14, 2016 (Total 31.82\%)

1) The party's stance follows a vote by the National Legislative Assembly (NLA) last week to add a second referendum question, asking the public whether parliament should jointly approve a prime minister for a five-year transitional period after a general election.

2) Citizens will be expected to vote on it at the Aug 7 referendum, along with a question on whether the charter draft prepared by the Constitution Drafting Committee (CDC) led by Meechai Ruchupan should be adopted.

3) Abhisit Vejjajiva said the party rejects the second question on the basis the senators are handpicked by the National Council for Peace and Order (NCPO).

4) The Democrat leader said the major political parties will have to join hands to ensure appointed senators do not get to decide who the prime minister will be.

5) The Democrat leader said the major political parties will have to join hands to ensure appointed senators do not get to decide who the prime minister will be.

6) He said that would have a bigger effect as it will give them a majority in parliament.

7) Mr Abhisit said the party has not made a decision on details of the charter draft but several members agree it contains many flaws and is not fit to be adopted as the country's supreme law.

8) He said while the charter draft is designed to rein in corruption, it drops the need for impeachment

9) "We can't afford to be in this situation. The NCPO should assure everyone that no matter what the outcome of the referendum, we won't be headed towards another violent conflict," he said.

10) Saying they were afraid the NCPO would succeed in implementing reforms and people would not vote for them. 
11) He also said the politicians hardly solved any problems but were in fact a part of them.

12) Saying it is intended for the whole country, not just certain groups of people.

13) He expressed confidence the Election Commission would be able to hold an impartial referendum.

D. Frequency of Complex sentence used in the selected Thai political news: Frequency of Complex sentence used in the selected Thai political news.

\section{Frequency of occurrence in total}

Types of the Complex sentences

Number percentage

complex sentences

\begin{tabular}{lllll}
\hline $\begin{array}{l}\text { 1.Complex sentences } \\
\text { adverbials clauses }\end{array}$ & modified & by & 29 & 29 \\
\hline $\begin{array}{l}\text { 2. Complex sentences } \\
\text { relative clauses }\end{array}$ & modified & by & 27 & 27 \\
\hline $\begin{array}{l}\text { 3. Complex sentences } \\
\text { nominal clauses }\end{array}$ & modified & by & 44 & 44 \\
\hline Total & & $\mathbf{1 0 0}$ & $\mathbf{1 0 0}$ \\
\hline
\end{tabular}

\section{Discussion}

A sentence in English is usually divided into four types: a simple sentence, a compound sentence, a complex sentence and a compound - complex sentence. A complex sentence consists of the one main clause and one or more subordinate clauses. In reading any type of the text, one is likely to come across the complex sentence of one type or another in use. The reasons for using the complex sentence can be that in writing or communicating, occasionally it is very necessary to convey the message continuously so that the information is not interrupted. If there is any pause or any interruption, the idea being referred to may be incomplete, clumsy or uninteresting. The way to do this is to use the complex sentence. As this type of the sentence is typically longer, a sender of the message or writer may find it convenient to use this sentence. Thus, the best way probably to deal with the issue is to use one longer sentence. However, it is essential for the writer to take good care in writing the message in a complex sentence because he or she has to consider the level of the message meant for receivers or readers (Kolln, 1982). If the receivers or recipients of the message are not advanced, care should be taken to avoid several longer sentences. Otherwise, it is likely that the communication goal is likely to be unsuccessful. As for learners of English in general, it is not possible to avoid the complex sentence while they are reading some types of texts. Hence, it is very essential for them to understand or if possible, to master the complex sentence structure if they want to fully comprehend what is being sent or said. In any type of advanced texts, it is normal that more complex sentences are used. It is the learner's responsibility or duty to analyze the structure to get what is communicated. It can be said learner who do not fully understand the complex structure are unable to accurately grasp what is being referred to or described. The present study was conducted to draw more attention that this type of a sentence plays a vital role in English. Learners who want to improve their reading skill or other skills have to pay more attention to the complex sentences and their components. 
In the present study, the complex sentences which are modified by the nominal clauses are used with the highest frequency. The explanation could possibly be that the nominal clauses used in the selected news stories function as an object of the verbs. The verbs which are used with a higher frequency in this clause are: say, tell, suggest, advise. To completely convey an idea, these verbs required a complement or an object. To fill in the space, the nominal clauses are used to complete the ideas the person wants to communicate. The message looks incomplete if we say: they say... On contrast, it makes a perfect sense if the sentence is: they say that he will not come. The subordinate clause in the sample is a nominal clause. Furthermore, in the political news, the situations which require this type of the structure are common. As a result, the nominal clauses were found used with the highest frequency.

The clause which is ranked second is an adverbial clause. The adverbial clause functions like an adverb in the sentence. The reasons to explain the use of this type with the second frequency are that: as the situations reported in the news happened in different times, places and to different persons, hence it was natural to report the incidents using different types of adverbial clauses. If the situation was focused on time, an adverbial clause of time was used. If the incident demanded something about the place, it was common to use an adverbial clause of place. As a result, the adverbial clauses were found to have been used with the second highest frequency in the present study.

The type of the clauses which is least used in the news stories in the study is the relative clause or adjective clause. An adjective normally describes, modifies and identifies the nouns. Like an adjective, the adjective clause is used to describe the head nouns. However, it does not necessarily mean that the head nouns have to be always modified by the clause. At times, the head nouns can also be modified by a phrase. As a result, this type of a clause is not used as frequently as the others. Furthermore, as the relative clause can be modified indefinitely. In other words, theoretically speaking, the relative clause can be as long as the writer wishes. Faced with the longer relative clause, readers may find the sentences confusing and unintelligible. In other words, instead of giving a clear message, the longer relative clause may cause confusion to readers. Thus, careful users of English use the relative clause with a moderate length to avoid causing confusion and misunderstanding among the learners. The finding of the present study is similar to the study by Klongsoongern (1999) who conducted a research on the Analysis of English Usage in Political news in English Language Newspaper. The results of the study found that considering the four sentences used in the newspaper in the study, the complex sentence was most frequently used. Other types of the sentences found in her study were arranged in a descending order: a simple sentence, a compound sentence and a complex - complex sentence.

\section{Conclusions \& Recommendations}

The present aimed to analyze complex sentences and study the types of the complex sentences as used in the selected Thai political news stories from online Bangkok Post. Four Thai political news stories were selected for the study. They were the news stories published in April 2016. The news stories were analyzed based on the following types: adverbial clauses, relative clauses/adjective clauses and nominal clauses. The study found that the type of complex sentences which was used with the highest frequency was a nominal clause. It accounted for $44 \%$. The type of the complex sentences which was ranked second in use was an adverbial 
clause. It accounted for $29 \%$. The type of the complex sentences which was least used was a relative clause. It accounted for $27 \%$.

\section{General Recommendation}

English Teacher can use the complex sentences which are modified by different clauses to teach English. It is, however, advised that the samples of the complex sentences to be used in teaching should not be long and difficult. It is very essential for the teacher to consider the level of learners to maximize the benefits for learners.

\section{Recommendations for Further Research}

An analysis can be conducted on the complex sentences used in other types of news, for example, education news, international news, entertainment news, etc.

A comparative study can be conducted on various sentences used in different type of the texts.

\section{Acknowledgements}

This study would not have been completed without the kind help from many people. First of all, I would like to express my deep sincere acknowledgements and appreciation to my advisor, Prommintra Kongkeaw, Ph.D. He always gives me encouragements and suggestions that make this study become a reality. I am deeply grateful to all instructors of English of Graduate School, Ubon Ratchathani Rajabhat University, for their encouragement and valuable guidance. I am also thankful to Asana Cherdchoo Ph.D., external examiner. My special thanks go to the director, the teachers, and the students at Photharam Technical College for their kindness and help. The last but not least, I am thankful to my beloved family who supports me in many ways until the I.S. has been completed.

\section{References}

[1] Jarvie, G. (1993). Grammar Guide. Paragon: London.

[2] Kansuwan, S. (1994). Introduction to Newspaper. Bangkok: Prakaipruek.

[3] Klongsoongern, B. (1999). An Analysis of Headlines of The Bangkok Post and The Nation on The Meaning of Vocabulary and the Structures of Sentences and Phrases. Taksin University Songkhla: A Master's Thesis of Education Degree in English.

[4] Kolln, B. (1982). Understanding English grammar. New York: Macmillan Publishing Co., Inc.

[5] Meksujit, S. (2002). Grammatical structures used in the business sections of the Nation and the Bangkok Post: A case study. Master's Thesis, King Mongkut's Institute North Bangkok.

[6] Phanphanich, P. (1999). An Analysis of English Usage in Political News in English Language Newspaper. Master Project of Arts, Communicative English, Graduate School, Ramkhamheang University.

*Corresponding author.

E-mail address: nootprapa@gmail.com 